\title{
"New life" for defence military architecture: the case of the sighting towers in Basilicata
}

\author{
A. Guida ${ }^{1}$, A. Pagliuca ${ }^{1} \&$ G. Damone ${ }^{2}$ \\ ${ }^{1}$ Department of European and Mediterranean Cultures: \\ Architecture, Environment, Cultural Heritage (DiCEM), \\ University of Basilicata, Italy \\ ${ }^{2}$ Department of Civil Engineering, University of Salerno, Italy
}

\begin{abstract}
Since the time of Roman Empire possession, the need to defend and guard the territory from foreign incursions has been felt, especially in peripheral or coastal areas. For this reason, numerous towers were built; they form just a part of a larger communication system, in which each tower was in line with the next, communicating through a telegraph or semaphoric system, via a complex system of bright reflections using fires, smoke or mirrors and sometimes even with a warning signal (bells). The research, which focuses on a portion of the Ionian Sea coastal area (Basilicata, Italy), through a study of the defensive system of sighting, aims to highlight, besides the obvious functional system, the very close characteristics of shape, architectural and typological types, that connect these towers and assimilates them to the typical forms of military architecture (regular shapes, closed on the outside and massive). Through a technological and constructional analysis, the study aims to propose a new life for these architectures that have lost their primary function and, now, are abandoned and in an evident state of decay, as ruins. In fact, the fundamental elements of the conservation debate consists of the opposition between material and image conservation; the balance between these two terms is a third element, the value of the building. The most current guidelines suggest an integrated conservation, as the combined result of the techniques, interventions and user needs: the goal is to ensure continuity of life of this heritage through a suitable use. It is also a necessary condition for conservation intervention that exceeds the concept of protection to become an important way to build the future, as part of the social, economic and cultural territory in which these buildings are located.

Keywords: defence architecture, suitability, reuse, value, construction systems.
\end{abstract}




\section{Introduction}

The study of built heritage is an important step for the knowledge of the past. In fact, the ability to analyse the historical architecture allows us both to value and to describe (from an architectural and functional point of view) monumental buildings or widespread minor constructions as well as the approach to the traditional construction systems, in order to operate a suitable recovery intervention. The study of construction systems - through a direct comparison with the historical built heritage - allows us to understand what is known as well-done construction systems, i.e. the set of unwritten rules and handed on from generation to generation; in fact, that analysis is fundamental to design recovery interventions in the idea that each building is unique and unrepeatable. So the recovery of built heritage assumes a central role also in the academic debate; the documentation of architecture of the past allows to guarantee the memory for future generations: in fact, to detect and map the building characteristics means to determine an image defined over time. This research, which focuses upon the towers of the coastal area in Basilicata (Italy), aims to show a new life of this crystallized heritage. In fact, they have ceased function for which they were built and have become museums of themselves; it is uncertain what could be a new suitable function that takes into account the historical and architectural characteristics of that built heritage.

\section{An inheritance from the past: military architecture as past defence}

The issue of the wall fortifications of the cities (or territories) has always been a central node for the architectural debate. The danger of enemy invasion led to build fortifications that would respond to the needs of defence, but - at the same time that was in the construction rapidly and cheap as well. With particular regard to the Basilicata, the first fortifications systems - today known - was built in IV century BC These fortifications was boundary wall of inland city centers (Serra di Vaglio, Torretta di Pietragalla, Croccia Cognato, Satriano, Baraggiano, Muro Lucano e Monte Coppolo di Valsinni) that emulate the defensive walls of the Greek colonies. Except for Muro Lucano e Monte Coppolo, these walls were built with a double masonry face, where the outer one is composed of square sandstone blocks; while, in Monte Coppolo, the outer masonry face is built using large limestone blocks with an irregular shape.

In addition to the above examples, there are written evidences that certify the importance of the military architecture (i.e. a part of X book of Vitruvius (30 BC), the technical part of the wartime writings of Julius Caesar, IV and V books written by Philo of Byzantium in 120 BC; more information on Roman fortifications can be inferred from historical reports such as those of Polybius and Livy [1]).

But more than cities' defence, great attention is put to coastline defence, that is a part of territory extremely vulnerable to attacks from the sea. But the coastline control and defence seems to stop as soon as it has the conquest by the Romans of the entire perimeter of the Mediterranean area that will make useless all the 
sighting constructions built before. It is only with the collapse of the Empire that will represent the problem of seaside defence [2].

In fact, around the VII century there was a worsening of situation as result of Islamic expansion in the Mediterranean area: in a short time the southern seaside coast become the place of bloody naval battles [2, p. 34]. Thus, it began the so called "Sea War"; that war aims to control the routes of merchant ships in the Mediterranean Sea: in fact, to check the sea meant to monitor the exchange of goods as well as to make a siege to enemy populations blocking the supply of necessaries that travel mainly along shipping routes.

So, a sighting structures was built to control the territory; they was placed on a rise to guarantee a visual connection between the different sighting towers and between the tower and the other architectural defence system (i.e. castles) as well. These architectural systems were able to guarantee visual communications between them, using light and smoke signals.

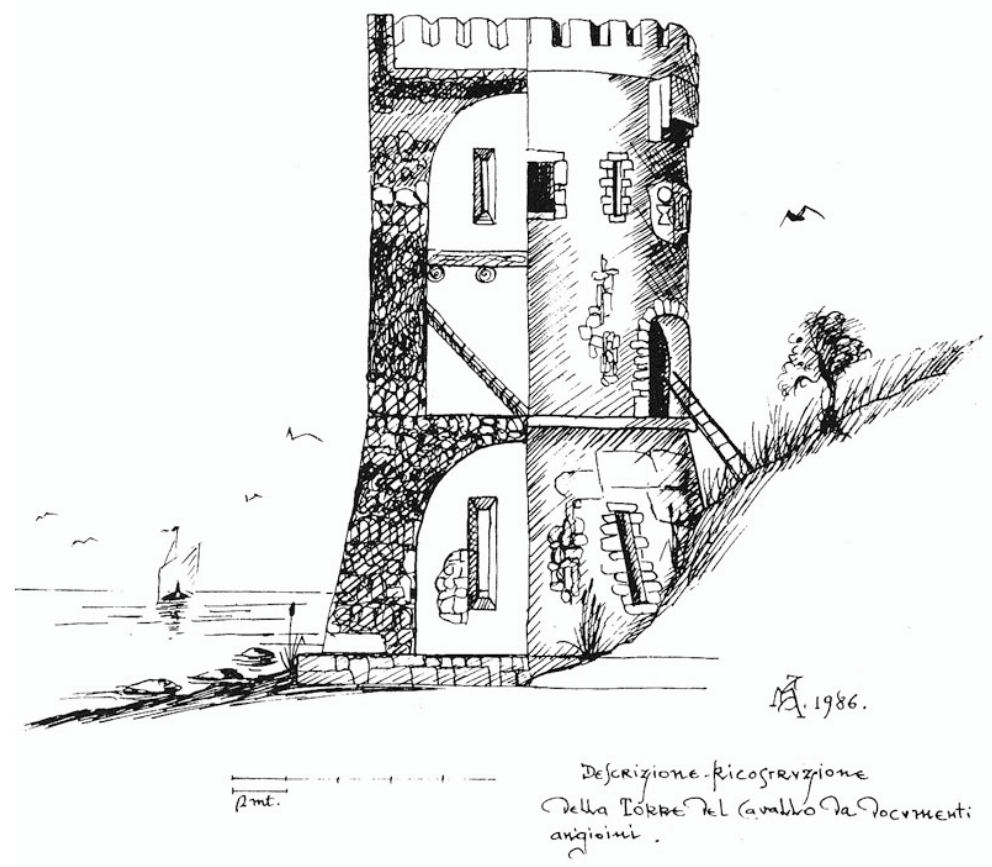

Figure 1: Example of reconstruction of an ancient tower ("Torre Cavallo", engraving of Giuseppe Maddalena, in ALEPH, n. 12, Brindisi, 1986).

An impressive requalification intervention of the above said architectural defence systems was made from the Angevins (fig. 1), who operate a refurbishment and an implementation of the built towers. At this age, it belongs to the structures with a square or circular basement, with large walls and with an escarpment at the base of the tower that allows a rebound of material launched from the top. 
In this way it increased a communication system (already known from the Greeks), in which each tower was in line with the next and communicated through a telegraph or semaphoric system, via a complex system of bright reflections using fires, smoke or mirrors and sometimes even with a warning signal (bells) [2, p. 44].

\section{The Ionian coast at the end of the past culture}

The Ionian coast of Basilicata is characterized by its geographical position as well as by its role in ancient times (Magna Grecia). It's during the first half of VII century BC that some Greek populations - expelled from Turkey - founded a settlement (called Siris) between the mouth of the river Agri and Sinni. Archaeological excavations have revealed a settlement with an irregular shape, fortified using clay bricks, situated on a rise called "Baron's Castle" and not with sacred areas and monumental necropolis nearby.

A century later, in $640 \mathrm{BC}$, a settlement (called Metaponto) was founded at the mouth of the river Bradano and Basento, by people coming from the Peloponnese; after its foundation, Metaponto recorded a big urban growth and became one of the most important city in the Ionian coast.

With the Roman conquest of the III century BC, Metaponto underwent a gradual reorganization with a consequential abandonment of the surrounding areas that led the city to turn into a swamp area.

Soon, the Ionian coast suffered a slow abandonment; in fact, with the Romans, it will be preferred other territories in Basilicata to create new cities, headquarters of the political and economical functions of the area. All the coastal areas become marshland and malarial.

In this situation, it comes to the Middle Ages, in which there was a population movement from the coast side to internal part of the territory and, then, a reorganization of the whole territory.

Some of the settlements (i.e. Montescaglioso, Camarda (today Bernalda), Pisticci, Montalbano, Anglona, Tursi, Bollita (now Nova Siri), Petrolla (a settlement which has disappeared) and Rotondella) are sites about fifteen kilometre inland and at an altitude of three hundred to four hundred metre on sea level, along a line parallel to the coast [3].

Only in the second half of XI century, there was a slow recovery of countryside life, where the centers are fortified and connected to the local monastic communities [4]. After another decline period, in the second half of XV century new monastic communities restoring the centers previously abandoned and the economic activities, as well; all the coastal settlements are expanded [3, p.11].

A different situation is present on the Tyrrhenian coast of the Basilicata (fig. 2), where the different morphology of the soil leads to different settlements typology (very different between them); the most important settlements were identified in two centres entrenched and inaccessible: Maratea Superiore (known as "the Castle”) and the large landed estate of Castrocucco [5]. 


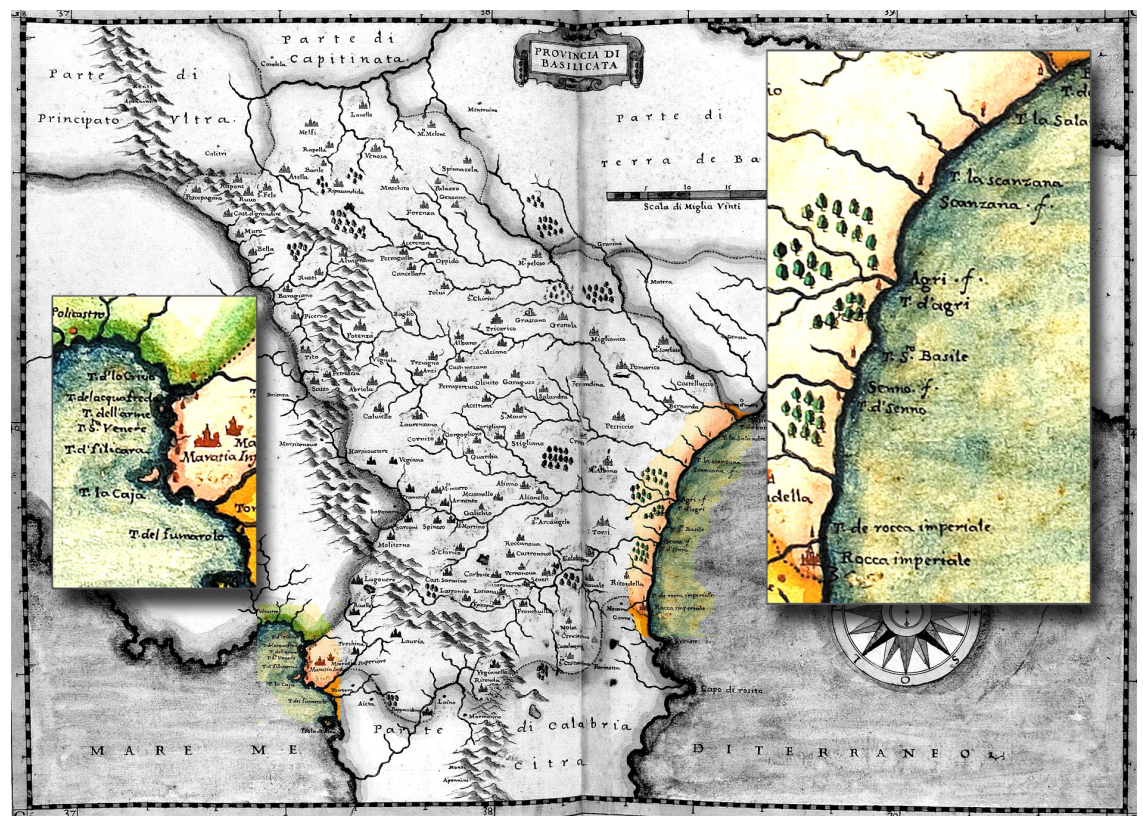

Figure 2: Individuation of Basilicata tower in Mario Cartaro plants (1613).

\section{The coastal tower between "function" and "matter"}

At the beginning of the XVI century, after important events such as the landing of the Turks in Salento (1480) and the siege of the city of Otranto, there was the necessity to improve the coastal security. In this context, the local government prepared a detailed project for the safety which involves the construction of sighting towers as well coastline defence systems (which integrate the existing ones); at the end of the XVI century the fortification process of the Ionian coast has ended. This defence systems consists in a series of fortified settlements (situated parallel to the coast, inland of territory), of rural settlements (fortified and located between the coast and the above said inland fortified settlements, whose function was to sight and to refuge the populations in case of enemy attack from the sea), and the coastal towers built to improve the existing defence systems [5, p. 33]. On the Tyrrhenian Sea, instead, the settlements was on the top of mountains (close to the sea), because of the morphology of the territory. The first mentioned settlements of Castrocucco was slowly abandoned for the lack of accessibility as well as Maratea Superiore from where there was a slow migration of population to the new fortified settlements in Maratea Inferiore (that soon became an important centre for the commercial routes); Maratea Superiore became just a defensive settlements to retreat in case of enemy siege [5, p. 35].

In addition, the towers' construction will also lead to dislocate the population along the coast and the construction of small settlements close to the towers [3, p. 16]. Today, there are only nine towers of the entire coastal towers systems built 


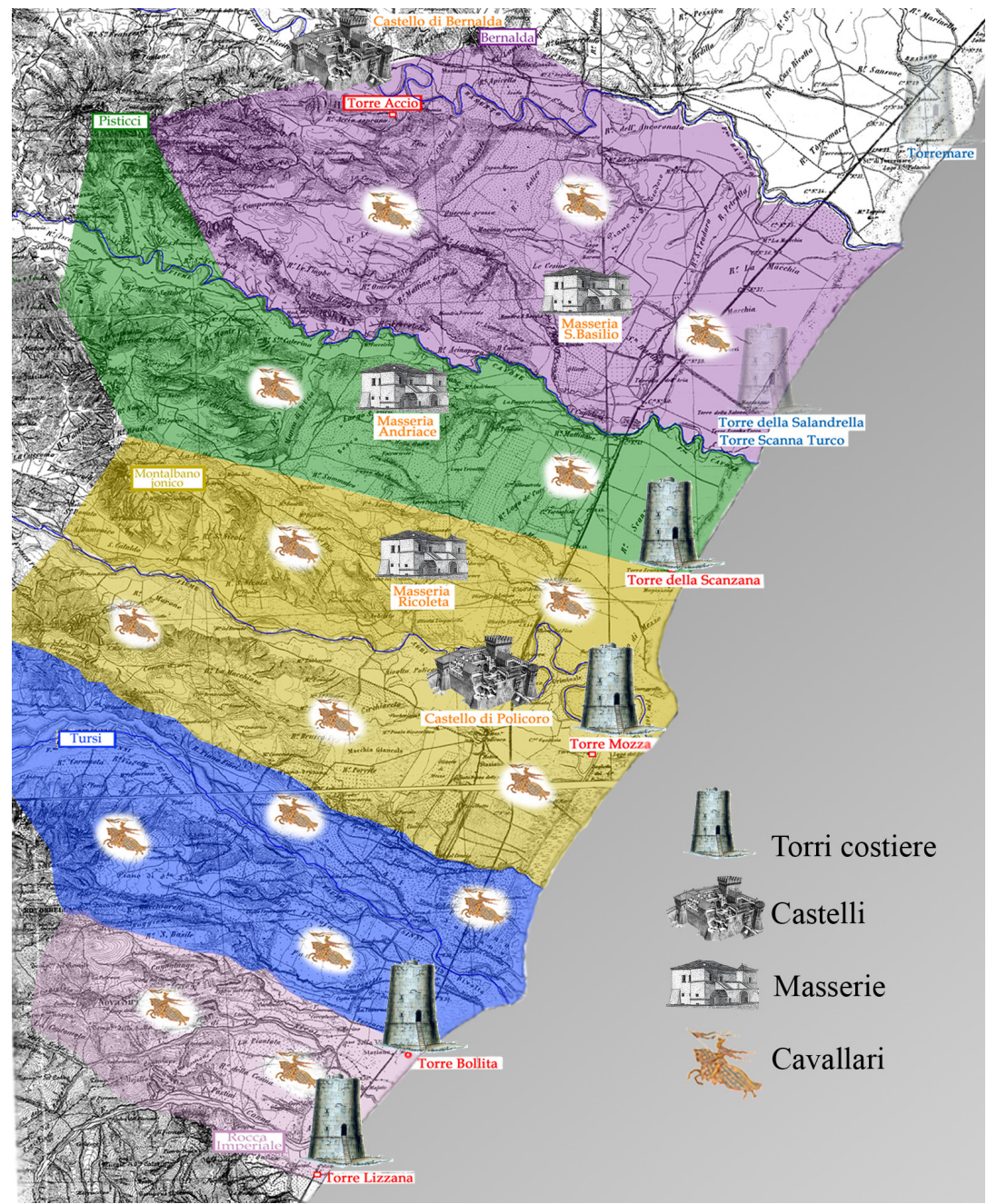

Figure 3: Ionian coast organization.

in Basilicata over the centuries; three of them are placed on the Ionian coast (fig. 3), "Torre Bollita", "Torre Mozza" and "Torre Scanzana”.

The different morphology of the site has led to use different shape of tower but all of them present a similar technological and constructional characteristics. In fact, the Ionian towers always have two levels in order to increase the range of vision. Another similarity between the structures is the use of construction materials available in situ: river pebbles, sandstone, brick, local stone called "tufo" and lime or pozzolanic mortar (fig. 4). 

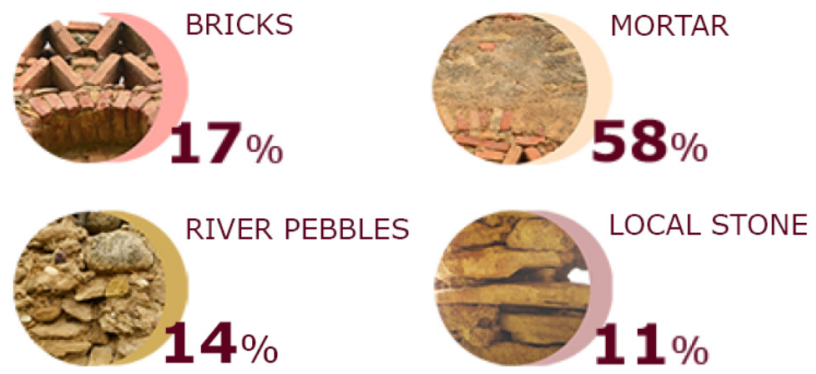

Figure 4: Tower construction materials.

The first structure built on the Ionian coast was the "Torre Bollita". It was probably built before the XVI century; it shows a lot of typological and constructive characteristics similar to those built in Puglia. It is located in a little city called Nova Siri (whose ancient name was Bollita).

Its circular structure is partially incorporated in a farmhouse built close to the sea. Some historical sources (fig. 5), show that the tower was already in ruins in 1568 and, although used as a reference to allocate parts of the coast to different knight, was not considered in the above said requalification project of defence systems. It is certain that when there was the abandonment of the coastal sighting system, the tower was bought by private owners and, after the land reclamation of the coastal area, it became a farm. In that occasion, the tower was restored and added two storey, one of which will remain incomplete; they was designed to accommodate the owners. It also redefined the exterior windows and made a new entrance; the original main door (placed at a greater height for reasons of defence) will be transformed into a window [5, p. 34]. A string-course elements characterize the facade of the tower; there is also a crowning element at the top are realized in local stone (fig. 6).

Instead, "Torre Mozza" and "Torre Scanzana" are attributable to the project of the XIV century and - given the strong structural and typological similarities between them - it's possible to hypothesize that they was built by the same workers. "Torre Mozza" is in the territory of Policoro a little town closed to the mouth of river Agri. Today, it is called "Mozza" because it has only the first level

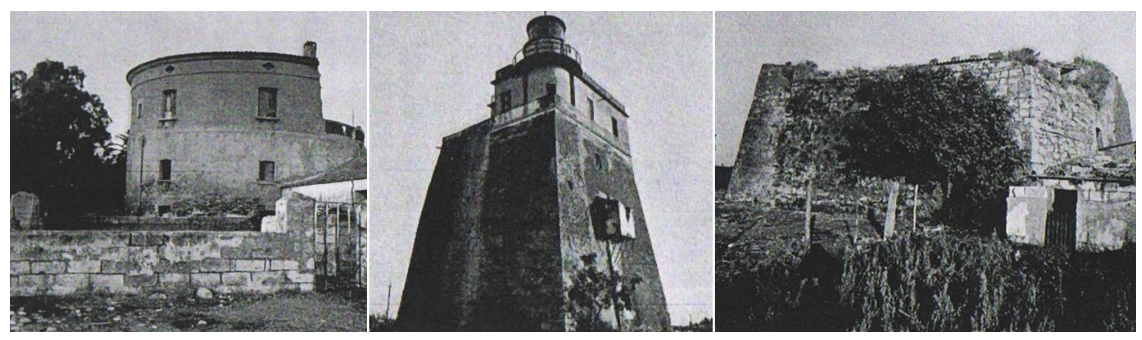

Figure 5: Historical images of Ionian Tower (Bollita, Scanzana and Mozza). 
of the structure while the other one was destroyed. From the study of ancient cartography, however, it is possible to deduce that the original name was "Torre dell' Agri", as reported in Mario Cartaro plants drafted in 1613.

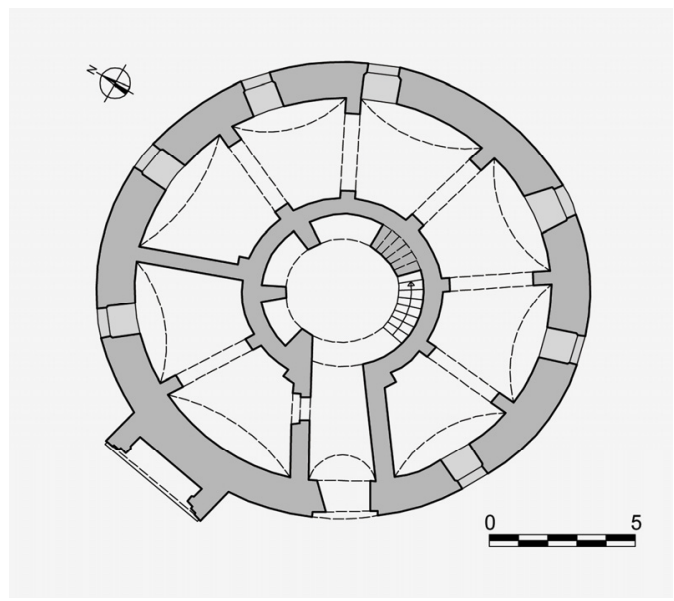

Figure 6: Tower Bollita, circular plant.

It was planned in 1563, while it was built only three years later. Since 1596, however, there are documents that attest to its use [5, p. 43].

The tower is also mentioned in a representation of the estate of Policoro in 1589 where it is drawn near the mouth of river Agri, not far from the coast; in the same map is also detectable the "Torre di San Basilio" (built close to Sinni river) and the Policoro Castle [5, p. 39]. Looking at the ruins, today it is possible to understand that it has a considerable size; it was built in poor quality masonry walls (fig. 7), in which was used little blocks of local stone, sand and brick; only in the corners, in the doorposts and architrave of doors and windows are used wellworked blocks of tufo that (probably) coming from the ruins of the nearby city of Heraclea.

Today, only the ground floor of the tower remains with (a) the main door realized after the abandonment of the structure, (b) the strongly splayed window and (c) the original entrance to the tower placed three meters from the ground floor. In addition, there are three niches in the wall that had to serve as a small service areas, while a staircase, in the thickness of the wall, made it possible to reach the next level and the terrace, both collapsed today.

Not far from the just described tower, is the "Torre del Faro". It is located in the territory of Scanzano Jonico, in a very unsafe place for the possibility of easy enemy attack; the structure is in excellent condition. The original name was "Torre Scanzana" or "Torre dello Scanzo" or "Lighthouse"; it was built in 1563 $[5$, p. 45].

The tower has a square plant (14.30 x 14.30 meters) and is divided into two levels with unique space and with small compartments formed in the thickness of 

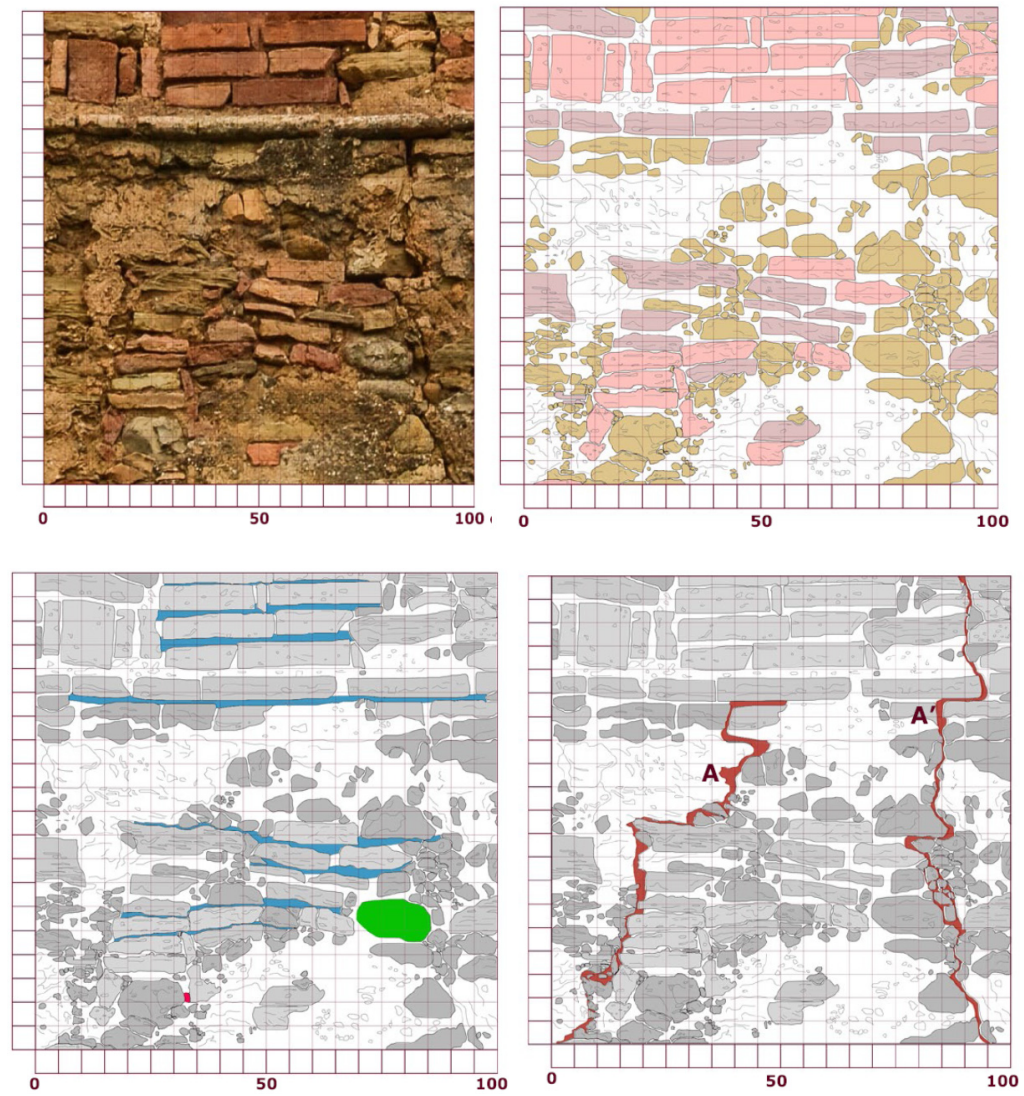

Figure 7: Quality characterization of masonry.

the wall (fig. 8). Both the floors are covered with barrel vaults orthogonal between them to reduce the action of forces on the walls.

Outside the tower a cistern for rainwater collection is detectable; as for the "Torre Mozza", the masonry walls are mixed with course of river stone and with rows of limestone blocks square. At the top, it was used bricks, probably linked to maintenance work carried out over the time. In the fifties of the last century, in the upper part of the tower was added a lighthouse and a new level that was to host the guardian house, while in the inferior two levels was built partitions and a balcony. All the additions (except for the lighthouse) were demolished during recent restoration work undertaken by the local government.

There are also a minor examples of defence sighting tower: the "Torre Salandrella" and "Torre dell'Accio" in Pisticci built in 1563 and the "Torre del Mare" and "Torre San Salvatore" in Bernalda [6]. 

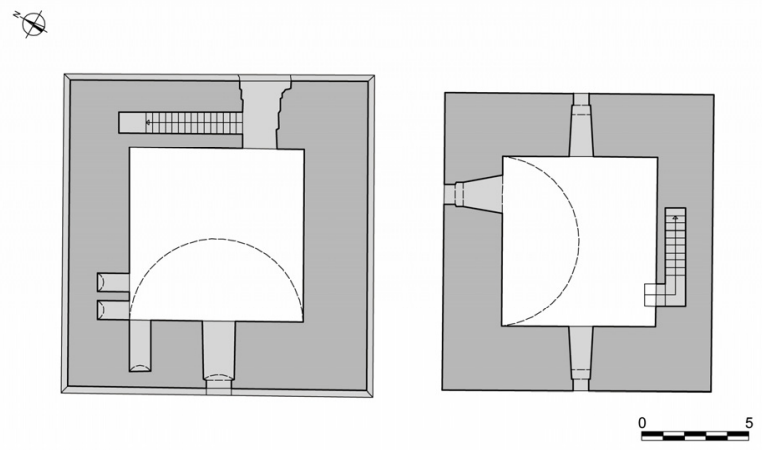

Figure 8: Tower Mozza, square plan.

\section{From the past to the future: a "new life" for the towers}

“To know means to hand down to posterity": it is a fundamental concept in actual debate on restoration and reuse of built heritage. The conservation of built heritage, in fact, becomes a core element around which are structured complex research fields that comes from architectural survey and historical documentation, to the analysis of the traditional technical and technological construction systems, to the study of the forms of damage and degradation. To analyse an architecture means recognizing to it a formal, technical and technological values as well as its historical stratification: the building becomes a monument to itself.

In fact, if the restoration intervention is an expression of an attitude that manifests a way to attribute a specific value to an architecture, to restore means to decide that an object is important, although it is largely compromised. Moreover, the ruin (and the analysed towers can be identified in this taxonomic category) was placed by Cesare Brandi as an extreme case of restoration project and - at the same time - as a starting point of restoration project, as well.

The debate of conservation intervention is, in fact, on the dichotomical relationship between matter conservation and image conservation: the mediation between these two terms is a third element, consisting in the recognition of a value or a value system for an architecture. The most current guidelines of the conservation method seem to lead in a way of integrated conservation (as set out in the Charter of Amsterdam, 1975) as a result of the combined techniques of restoration and research of suitable functions: the objective is to guarantee the continuity of life of built heritage through its suitable use. So, the restoration intervention becomes a cultural act (in its broadest meaning) opened to use and reuse, to material and technological needs, to territorial and town planning components, as well as to the ecological and environmental ones: preservation is never either just this, or pure preservation, but always controlled transformation, where the term transformation represents a less schematic and more appropriate and flexible way to meet the building to the requirements expressed by the users.

In fact, the requirements expressed by the users must be considered as normal elements of design: in this way it could be developed a progressive and critical 
idea of the restoration intervention that is defined as a characteristic act of the present time and not as a freezing action: the conservation, in fact, looks to the future and not to the past.

\section{References}

[1] Cassi Ramelli A., Dalle caverne ai rifugi blindati. Trenta secoli di architettura militare, Maria Adda Editore: Bari, p. 51, 1996.

[2] Russo F., Le torri costiere del Regno di Napoli. La frontiera marittima e le incursioni corsare tra il XVI ed il XIX secolo, Edizioni scientifiche ed artistiche: Napoli, p. 32, 2009.

[3] Bubbico L., Caputo F., Tataranno A., (a cura di), Il sistema difensivo in Basilicata le torri costiere, Tipografia Olita: Potenza, p. 9, 1995.

[4] Bixio A., Torri di mare e osservatori di paesaggi costieri, Grafie: Potenza, pp. 32-33, 2008.

[5] Bixio A., Torri di mare e osservatori di paesaggi costieri, p. 32.

[6] Faglia V., Tipologia delle torri costiere nel Regno di Napoli. Le torri costiere della Provincia di Basilicata, Istituto Italiano dei Castelli: Roma, p. 76 ss., 1975. 